\title{
PENERAPAN PENDEKATAN METAPHORICAL THINKING UNTUK MENINGKATKAN KEMAMPUAN REPRESENTASI MATEMATIS SISWA VIII MTSN 1 ACEH BESAR
}

\author{
Husny Mubarak ${ }^{1}$, M. Yacoeb Harun ${ }^{1}$, Yassir $^{1}$ \\ ${ }^{1}$ Universitas Islam Negeri Ar-Raniry, JalanSyeikh Abdur Rauf, Banda Aceh 23111, Indonesia \\ Email: husniaceh16@gmail.com \\ Email: yacoeb@ar-raniry.ac.id \\ Email: yassir@ar-raniry.ac.id
}

\begin{abstract}
Masalah yang sering terjadi sekarang dalam matematika adalah bagaimana mengajar matematika menjadi lebih baik?,Mengajar hanya dengan berbicara bisa disebut dengan pendekatan tradisional dan tidak cukup lagi, karena pendekatan ini mengabaikan kemampuan kognitif dan perbaikan diri setiapsiswa. Dalam konteks ini menunjukkan bahwa siswa kurang terlibatdalam proses pembelajaran yang menghubungkan gagasan atau ideide matematis siswa, Kemampuan representasi matematis adalah kemampuan dalam menyajikan ide-ide matematika dalam bentuk gambar, model matematika, serta teks tertulis dari suatu konsep atau permasalahan yang diberikan. Salah satu alternatif yang mampu mendukung upaya peningkatan kemampuan representasi matematis siswa, yaitu penerapan pendekatan metaphorical thinking. Tujuan dari penelitian ini adalah untuk mengetahui apakah dengan penerapan pendekatan metaphorical thinking dapat meningkatkan kemampuan representasi matematis siswa. Pada penelitian ini, peneliti menggunakan pendekatan kuantitatif. Desain penelitian ini kuasi eksperimen jenis one-Group-Pretest-Postest. Subjek penelitian ini adalah siswa kelas VIII-1 yang terdiri 23 orang.Teknik pengumpulan data menggunakan tes, sedangkan uji-t dengan bantuan SPSS 22 setelah data dikonversikan ke skala interval dengan bantuan MSI. Hasil penelitian menunjukkan bahwa penerapan pendekatan metaphorical thinking dapat meningkatkan kemampuan representasi matematis siswa pada kelas VIII MTsN 1 Aceh Besar. Hal ini dapat dilihat berdasarkan hipotesis, didapat nilai sig (2-tailed) adalah 0,000 dengan $\alpha=0,05$, maka kriteria pengujian diperoleh $0,00<0,05$. Berdasarkan criteria pengambilan keputusannya, H_0 ditolak dan terima H1. Tingkat kemampuan representasi matematis siswa sebelum diberiperlakuan rata-rata persentasenya adalah 50\% tergolong kategori rendah, akan tetapi setelah diberi perlakuan pada pembelajaran dengan menerapkan pendekatan metaphorical thinking kemampuan representasi matematis siswa mengalami peningkatan. Hal ini terbukti dengan skor rata-rata persentase $81 \%$ tergolong pada kategori sangat tinggi.
\end{abstract}

Keywords: Representasi Matematis, Pendekatan Metaphorical Thinking

\section{PENDAHULUAN}

Harapan dari siswa saat ini membutuhkan instruksi matematika yang melampaui apa yang dibutuhkan oleh siswa di masa lalu. Hal ini merupakan tantangan yang signifikan untuk guru matematika agar dapat mengalami perubahan besar tidak hanya diisi materi matematika yang mereka ajarkan, tetapi juga dalam cara mereka mengajar (Sulis Widarti,dkk, 2014).

Masalah yang sering terjadi sekarang dalam matematika adalah bagaimana mengajar matematika menjadi lebih baik?, Mengajar hanya dengan berbicara bisa disebut dengan pendekatan tradisional dan tidak cukup lagi, karena pendekatan ini mengabaikan kemampuan kognitif dan perbaikan diri setiap siswa. Dalam konteks ini menunjukkan bahwa pendekatan pembelajaran dapat berperan untuk memahami penggambaran matematika secara menyeluruh dengan menunjukkan penerapan matematika dengan kehidupan nyata (Muharrem Aktümen, 2015). 
Representasi sekarang menjadi salah satu pusat studi matematika. Siswa dapat mengembangkan dan memperdalam pemahaman mereka tentang konsep-konsep matematika dan hubungan yang mereka buat, membandingkan, dan menggunakan berbagai representasi. Representasi matematis dibagi kedalam tiga bentuk indikator, yaitu (1) representasi berupa diagram, grafik, atau tabel, dan gambar; (2) persamaan atau ekspresi matematika; (3) kata-kata atau teks tertulis (Mokhammad Ridwan, 2015), Penggunaan representasi oleh siswa dapat menjadikan gagasangagasan matematis lebih konkret dan membantu siswa untuk memecahkan suatu masalah yang dianggap rumit dan kompleks menjadi lebih sederhana jika strategi pembelajaran yang digunakan sesuai dengan permasalahan tersebut.

Berdasarkan penelitian yang dilakukan oleh Puji Syafitri Rahmawati tentang kemampuan representasi matematika pada siswa SMP Negeri 32 Bekasi tahun ajaran 2014/2015, menunjukkan bahwa kemampuan representasi matematika siswa yang ia teliti masih tergolong rendah. Hal ini disebabkan oleh beberapa faktor, yang di antaranya adalah kurangnya kemampuan siswa untuk mengungkapkan gagasan atau ide, kurang memahami dalam membuat cerita atau kalimat dari sebuah gambar atau grafik, pendekatan pembelajaran yang diterapkan cenderung teoritik dan kurang berhubungan dengan kehidupan sehari-hari. Di dukung juga dengan observasi peneliti pada saat PPL. peneliti mendapatkan bahwa siswa kurang memahami soal dalam bentuk cerita dan menggambar pola-pola, dikarenakan siswa belum bisa memahami soal dalam bentuk cerita. Selain itu, observasi awal yang dilakukan peneliti melalui tes kepada beberapa siswa di kelas VIII di sekolah tujuan penelitian, menunjukkan bahwa mereka belum begitu memahami apa yang telah dipelajari dan mereka merasakan kesulitan dalam menyelesaikan soal, terutama soal yang berbentuk cerita dan gambar.

Dalam pendekatan pembelajaran Metaphorical Thinking guru memberikan siswa masalah kontekstual yang berupa metafora dari suatu konsep, kemudian siswa mengidentifikasi konsep yang terdapat pada masalah tersebut dan membuat metafora lain dari konsep tersebut. Dalam mengidentifikasi konsep, siswa harus mampu menghubungkan ide-ide matematis yang mereka miliki. Untuk menghubungkan ide-ide matematis tersebut siswa dapat merepresentasikannya melalui gambar, tabel, grafik, ekspresi matematis, maupun teks tertulis. Dengan demikian siswa menjadi terbiasa dengan metaphorical thinking yang merepresentasikan ide-ide matematis mereka.

Berdasarkan permasalahan di atas peneliti tertarik untuk mengangkat masalah ini menjadi suatu penelitian dengan judul "Penerapan Pendekatan Metaphorical Thinking untuk Meningkatkan Kemampuan Representasi Matematis Siswa."

\section{METODE PENELITIAN}

\section{Rancangan Penelitian}

Penelitian ini merupakan penelitian Kuantitatif menggunakan jenis penelitian Quasi Eksperiment dengan desain one-Group-Pretest-Postest. Adapun populasi dalam penelitian ini adalah kelas VIII MTsN I Aceh Besar dan sampel penelitian ini diambil dengan menggunakan teknik cluster random sampling, yaitu pengambilan kelompok kelas yang ada, dari kelas tersebut diundi kelas mana yang akan menjadi kelas eksperimen, dari teknik tersebut didapat kelas VIII-1 sebagai kelas eksperimen. Instrumen dalam penelitian ini adalah Rancangan Pelaksanaan Pembelajaran (RPP), Lembar Kerja Peserta Didik (LKPD) dan soal tes kemampuan representasi matematis siswa. Teknik pengumpulan data dalam penelitian ini yaitu dengan menggunakan tes awal (preetes) dan tes akhir (postes).

Metode eksperimen semu (quasi experimental) yaitu penelitian yang pada dasarnya sama dengan eksperimen murni, bedanya adalah dalam pengontrolan variabel. Penelitian ini mendekati 
eksperimen murni dimana tidak mungkin mengadakan kontrol atau memanipulasikan semua variabel yang relevan (Nana Syaodih, 2011).

Desain penelitian yang digunakan adalah dengan pola sebagai berikut:

Tabel 1. Desain Penelitian

\begin{tabular}{|c|c|c|c|}
\hline Kelompok & Pre-test & Perlakuan & Post-test \\
\hline Eksperimen & $\mathrm{T}$ & $\mathrm{X}$ & $\mathrm{T}$ \\
\hline
\end{tabular}

Keterangan:

$\mathrm{X}$ : Perlakuan yang dilakukan di kelas eksperimen yaitu pendekatan pembelajaran Metaphorical Thinking

$\mathrm{T} \quad$ : pree-test dan post-test

\section{HASIL PENELITIANDAN PEMBAHASAN}

Data yang akan di analisis pada penelitian ini adalah data tes kemampuan representasi matematis siswa pada materi pola bilangan.

Hasil pengolahan data penelitian diperolah data ordinal, Dalam prosedur statistik seperti ujian-t dan lain sebagainya, mengharuskan data berskala interval. Oleh sebab itu, sebelum digunakan uji-t, data ordinal perlu konversi ke data interval dalam penelitian ini menggunakan Metode Suksesif Interval (MSI). Setelah di konversi ke data interval maka selanjutnya di uji normalitas, uji-t serta menganalisis peningkatan representasi matematis siswa.

Tabel 2. Hasil Pretest Kemampuan Representasi Matematisdengan Menggunakan MSI

\begin{tabular}{|l|c|c|c|c|c|c|c|}
\hline \multicolumn{7}{|c|}{ Succesive Detail } \\
\hline Col & Category & Freq & Prop & Cum & Density & Z & Scale \\
\hline & 0 & 18 & 0,2609 & 0,26087 & 0,324923 & $-0,64067$ & 1 \\
\hline & 1 & 10 & 0,144928 & 0,405797 & 0,387768 & $-0,23837$ & 1,811914 \\
\hline & 2 & 13 & 0,188406 & 0,594203 & 0,387768 & 0,23837 & 2,24554 \\
\hline & 3 & 16 & 0,231884 & 0,826087 & 0,256757 & 0,938814 & 2,810523 \\
\hline & 4 & 12 & 0,173913 & 1 & 0 & td & 3,7219 \\
\hline
\end{tabular}

Tabel 3. Hasil Postest Kemampuan Representasi Matematisdengan Menggunakan MSI

\begin{tabular}{|c|c|c|c|c|c|c|c|}
\hline \multicolumn{9}{|c|}{ Succesive Detail } \\
\hline Col & Category & Freq & Prop & Cum & Density & Z & Scale \\
\hline 1 & 0 & 2 & 0,028986 & 0,028986 & 0,066126 & $-1,89592$ & 1 \\
\hline & 1 & 12 & 0,173913 & 0,202899 & 0,282386 & $-0,83131$ & 2,03786 \\
\hline & 2 & 11 & 0,15942 & 0,362319 & 0,374942 & $-0,35227$ & 2,700782 \\
\hline & 3 & 5 & 0,072464 & 0,434783 & 0,3936 & $-0,16421$ & 3,023877 \\
\hline & 4 & 39 & 0,565217 & 1 & 0 & 8,160727 & 3,977725 \\
\hline
\end{tabular}

Dalam representasi matematis aspek yang di ukur yaitu indikator representasi visual, representasi ekspesi matematis dan representasi kata-kata. dari indikator tersebut di peroleh hipotesis.

Adapun rumusan hipotesis dengan taraf signifikan $(\alpha)=0,05$. Hipotesis yang akan diuji adalah:

$H_{0}: \mu<70 \quad$ Pendekatan Metaphorical Thinking tidak dapat meningkatkan kemampuan representasi matematis siswa pada kelas VIII MTsN 1 Aceh Besar.

$H_{1}: \mu \geq 70 \quad$ Pendekatan Metaphorical Thinking dapat meningkatkan kemampuan representasi matematis siswa pada kelas VIII MTsN 1 Aceh Besar. 
Kriteria pengambilan keputusan untuk pengujian data tersebut jika signifikansi $<0,05$, maka $\mathrm{H}_{0}$ ditolak, Jika signifikansi $>0,05$, maka $\mathrm{H}_{0}$ diterima. Adapun nilai 70 merupakan nilai $\mathrm{KKM}$ untuk melihat peningkatan hasil belajar penelitian.

Tabel 4.Hasil Signifikansi kemampuan Representasi Matematis

\begin{tabular}{|c|c|c|c|c|c|c|}
\hline & \multicolumn{6}{|c|}{ Test Value $=0$} \\
\hline & \multirow[t]{2}{*}{$\mathrm{T}$} & \multirow[t]{2}{*}{ df } & \multirow[t]{2}{*}{ Sig. (2-tailed) } & \multirow[t]{2}{*}{$\begin{array}{c}\text { Mean } \\
\text { Difference }\end{array}$} & \multicolumn{2}{|c|}{$\begin{array}{l}\text { 95\% Confidence Interval of the } \\
\text { Difference }\end{array}$} \\
\hline & & & & & Lower & Upper \\
\hline Nilai & 9,519 & 22 & ,000 & ,609 &, 48 &, 74 \\
\hline
\end{tabular}

Tabel di atas terlihat bahwa nilai sig (2-tailed) adalah 0,000 dengan $\alpha=0,05$ ternyata nilai sig. (2-tailed) $<0,05$ maka $\mathrm{H}_{0}$ ditolak. Dengan demikian dapat disimpulkan bahwa kemampuan representasi matematis siswa pada kelas VIII MTsN 1 Aceh Besar mengalami peningkatan.

Data yang telah diperoleh selanjutnya akan disesuaikan dengan rubrik penilaian tes representasi matematis. Selanjutnya, data akan diolah dengan menentukan persentase keterpenuhan dari masing-masing indikator representasi matematis. Adapun Rublik dengan nilai 0,1, 2 di kategorikan rendah sedangkan nilai 3,4 dikategorikan baik/ baik sekali. Rumus yang digunakan untuk menghitung persentase keterpenuhan dari setiap indikator representasi matematis yaitu:

Keterangan

$$
\mathrm{P}_{\mathrm{j}}=\frac{Q_{j}}{r} \times 100 \%
$$

$\mathrm{P}_{\mathrm{j}}=$ Persentase Keterpenuhan Indikator Representasi Matematis

$\mathrm{Q}_{\mathrm{j}}=$ Banyak subjek yang memenuhi indikator Representasi matematis

r = Banyak Subjek (Melida, 2016)

Pada hal ini setiap skor yang diperoleh siswa akan digunakan untuk melihat kriteria tingkat kemampuan representasi matematisnya. Adapun kriteria klasifikasi skor penilaian kemampuan representasi matematis adalah sebagai berikut:

Tabel 5. Klasifikasi skor penilaian kemampuan representasi matematis

\begin{tabular}{|c|c|c|}
\hline No. & Persentase & Klasifikasi \\
\hline 1 & $81 \%-100 \%$ & Sangat tinggi \\
\hline 2 & $66 \%-80 \%$ & Tinggi \\
\hline 3 & $56 \%-65 \%$ & Sedang \\
\hline 4 & $41 \%-55 \%$ & Rendah \\
\hline 5 & $0 \%-40 \%$ & Sangat rendah \\
\hline
\end{tabular}

Sumber: (Adaptasi dari Arikunto,2001)

Sebelum melakukan penelitian, peneliti memberikan pretest kepada 23 orang siswa. Pretest yang diberikan berupa tes kemampuan representasi matematis siswa dalam bentuk essai yang terdiri dari 3 soal. Tujuan diberikan pretest adalah untuk mengetahui kemampuan awal siswa tentang kemampuan repesentasi matematis siswa. Kemudian setelah peneliti melaksanakan proses belajar mengajar dengan menggunakan pendekatan metaphorical thinking, peneliti memberikan posttest kepada 23 orang siswa. Soal yang diberikan berbentuk essay yang terdiri dari 3 soal yang dibuat berdasarkan indikator kemampuan representasi matematis siswa. Tujuan diberikan postest untuk melihat tingkat kemampuan representasi matematis siswa setelah diterapkan pendekatan metaphorical 
thinking. Dalam skor preetest dan postest kemampuan representasi matematis siswa kelas ekperimen dapat dilihat pada tabel berikut:

Tabel 6.Hasil Penskoran Tes Awal (pretest) Kemampuan Representasi Matematis Siswa

\begin{tabular}{|c|cc|c|c|c|c|c|c|}
\hline \multirow{2}{*}{ No. } & \multirow{2}{*}{ Aspek yang diukur } & \multicolumn{5}{|c|}{ Rubrik } & \multirow{2}{*}{ Jumlah } \\
\cline { 4 - 8 } & & & $\mathbf{0}$ & $\mathbf{1}$ & $\mathbf{2}$ & $\mathbf{3}$ & $\mathbf{4}$ & \\
\hline Soal 1 & 1. & Representasi Visual & 0 & 1 & 3 & 11 & 8 & 23 \\
\hline Soal 2 & 2. & Representasi Ekspresi Matematis & 11 & 8 & 2 & 1 & 1 & 23 \\
\hline Soal 3 & 3. & Representasi Kata-kata & 7 & 1 & 8 & 4 & 3 & 23 \\
\hline \multicolumn{2}{c}{ Frekuensi } & 18 & 10 & 13 & 16 & 12 & 69 \\
\hline
\end{tabular}

(Sumber: Hasil Penskoran Representsasi Matematis Siswa sebelum menggunakan pendekatan metaphorical thinking)

Tabel 7.Hasil Penskoran Tes Akhir (postest) Kemampuan Representasi Matematis Siswa

\begin{tabular}{|c|c|c|c|c|c|c|c|}
\hline \multirow[t]{2}{*}{ No. } & \multirow{2}{*}{ Aspek yang diukur } & \multicolumn{5}{|c|}{ Rubrik } & \multirow[t]{2}{*}{ Jumlah } \\
\hline & & $\mathbf{0}$ & 1 & 2 & 3 & 4 & \\
\hline Soal 1 & 1. $\quad$ Representasi Visual & 0 & 0 & 1 & 2 & 20 & 23 \\
\hline Soal 2 & 2. $\quad$ Representasi Ekspresi Matematis & 2 & 10 & 6 & 0 & 5 & 23 \\
\hline Soal 3 & 3. Representasi Kata-kata & 0 & 2 & 4 & 3 & 14 & 23 \\
\hline & Frekuensi & 2 & 12 & 11 & 5 & 39 & 69 \\
\hline
\end{tabular}

(Sumber: Hasil penskoran Kemampuan Representasi Matematis setelah pembelajaran)

Tabel 8.Persentase Skor Hasil Pretest dan Postest Kemampuan representasi matematis Siswa

\begin{tabular}{|c|l|c|c|c|c|}
\hline \multirow{2}{*}{ No } & \multirow{2}{*}{ Indiktor yang di ukur } & \multicolumn{2}{|c|}{ Tes Awal (Pretest) } & \multicolumn{2}{c|}{ Tes Akhir (Postest) } \\
\cline { 3 - 6 } & & Rendah & $\begin{array}{c}\text { Baik/baik } \\
\text { sekali }\end{array}$ & Rendah & $\begin{array}{c}\text { Baik/baik } \\
\text { sekali }\end{array}$ \\
\hline 1 & Representasi Visual & $17,39 \%$ & $82,6 \%$ & $4,34 \%$ & $95,6 \%$ \\
\hline 2 & $\begin{array}{l}\text { Representasi Ekspresi } \\
\text { Matematis }\end{array}$ & $91,3 \%$ & $8,6 \%$ & $78,26 \%$ & $21,7 \%$ \\
\hline 3 & Representasi Kata-kata & $69,56 \%$ & $30,43 \%$ & $26,08 \%$ & $73,91 \%$ \\
\hline & & $59,41 \%$ & 40,54 & $36,22 \%$ & $63,73 \%$ \\
\hline
\end{tabular}

Sumber: Hasil pengolahan data

Berikut ini adalah uraian dari tabel 8 mengenai hasil pretest dan postest kemampuan representasi matematis siswa kelas eksperimen.

1. Indikator Representasi Visual

Persentase kemampuan representasi matematis siswa dalam representasi visual kategori rendah mengalami penurunan dari yang sebelumnya $17,39 \%$ menjadi $4,34 \%$, sedangkan dalam kategori baik/baik sekali mengalami peningkatan dari yang sebelumnya $82,6 \%$ menjadi $95,6 \%$.

2. Indikator Representasi Ekspresi Matematis

Persentase kemampuan representasi matematis siswa dalam representasi ekspresi matematis untuk ketegori rendah mengalami penurunan dari yang sebelumnya 91,3\% menjadi 78,26\%, sedangkan dalam kategori baik/baik sekali mengalami peningkatan dari yang sebelumnya $8,6 \%$ menjadi $21,7 \%$. 
3. Indikator Representasi Kata-kata atau teks tertulis

Persentase kemampuan representasi matematis siswa dalam representasi kata-kata atau teks tertulis untuk ketegori rendah mengalami penurunan dari yang sebelumnya 69,56\% menjadi 26,08\%, sedangkan dalam kategori baik/baik sekali mengalami peningkatan dari yang sebelumnya 30,43\% menjadi $73,91 \%$.

Dari hasil tabel 5 menunjukkan bahwa kemampuan representasi matematis siswa terhadap seluruh indikator kemampuan representasi matematis dalam kategori rendah mengalami penurunan dari yang sebelumnya 59,41\% menjadi $36,22 \%$, sedangkan siswa yang berkategori baik/baik sekali mengalami peningkatan dari yang sebelumnya $40,54 \%$ menjadi $63,73 \%$. Maka hal tersebut dapat dikatakan bahwa penerapan pendekatan metaphorical thinking dapat meningkatkan kemampuan representasi matematis siswa.

\section{KESIMPULAN}

Berdasarkan hasil pengolahan data, dapat disimpulkan bahwa: Penerapan pendekatan Metaphorical Thinking dapat meningkatkan kemampuan representasi matematis siswa pada kelas VIII MTsN 1 Aceh Besar. Hal ini dapat dilihat berdasarkan hipotesis, dengan taraf signifikan $\alpha=0,05$. Kriteria pengujian diperoleh $0,00<0,05$. Berdasarkan kriteria pengambilan keputusannya, $H_{0}$ ditolak dan terima $\mathrm{H}_{1}$. Tingkat kemampuan representasi matematis siswa sebelum diberi perlakuan rata-rata persentasenya adalah 50\% yaitu siswa masih kurang dalam menginterpretasikan sebagian besar soal pada aspek representasi visual, sulit merepresentasikan kembali soal kedalam bentuk model matematika atau ekspresi matematis dan siswa masih sulit untuk menjelaskan jawaban menggunakan kata-kata dengan baik. Persentase skor tersebut berada pada kategori "rendah". Akan tetapi setelah diberi perlakuan pada pembelajaran dengan menerapkan pendekatan Metaphorical Thinking kemampuan representasi matematis siswa mengalami peningkatan. Hal ini terbukti dengan skor ratarata persentase $81 \%$ tergolong pada kategori sangat tinggi. Jadi, dapat disimpulkan dengan menerapkan pendekatan Metaphorical Thinking, tingkat kemampuan representasi matematis siswa mengalami peningkatan.

Mengingat pendekatan metaphorical thinking yang telah diterapkan pada siswa kelas VIII-1 MTsN 1 Aceh Besar dapat meningkatkan kemampuan representasi matematis siswa, maka disarankan kepada guru matematika untuk dapat menggunakan pendekatan metaphorical thinking dalam pembelajaran matematika.

Hasil penelitian ini hendaknya dijadikan masukan dan bahan pertimbangan bagi guru dalam merancang soal-soal representasi matematis dan pembelajaran yang menerapkan pembelajaran dengan menggunakan pendekatan metaphorical thinking sehingga dapat meningkatkan kualitas pembelajaran matematika.

\section{REFERENCES}

Muharrem Aktümen, Geogebra As An Artist's Paintbrush, Volume 4, No. 1, 2016. Diakses pada tanggal 01 Desember 2016 dari situs hitps:/eric.ed.gov

Sulis Widarti, Tina Yunarti dan Rini Asnawati, "Penerapan Model PBL Untuk Meningkatkan Kemampuan Representasi Matematis Siswa”,Jurnal Ilmiah, Vol. 2, No 4, 2014. Diakses pada tanggal 15 Desember 2016 dari situs http://jurnal.fkip.unila.ac.id/

Mokhammad Ridwan Yudhanegara, Meningkatkan Kemampuan Representasi Beragam Matematis Siswa Melalui Pembelajaran Berbasis Masalah Terbuka, Jurnal, Universitas Singa perbangsa Karawang, vol. 1, No. 4, Desember 2015. 
Herman Hudojo. (2005). Pengembangan Kurikulum dan Pembelajaran Matematika, Malang: UM Press.

Heris Hendriana. (2009). "Pembelajaran dengan Metaphorical Thinking untuk Meningkatkan Kemampuan Pemahaman Matematik, Komunikasi Matematik, dan Kepercayaan Diri Siswa Sekolah Menengah Pertama”, Disertasi, (Bandung: Universitas Pendidikan Indonesia)

National Council of Teachers of Mathematics. (2000). Principle and Standards for School.

Leo Adhar Effendi, "Pembelajaran Matematika Dengan Metode Penemuan Terbimbing Untuk Meningkatkan Kemampuan Representasi dan Pemecahan Masalah Matematis Siswa SMP"Jurnal Ilmiah, Vol. 13, No. 2, oktober 2012. Diakses pada tanggal 16 mei 2016 dari situs http://jurnal.upi.edu

Melida, Konferensi Nasional penelitian Matemtika dan pembelajarannya (KNPMP I) Universitas Muhammadiyah Surakarta, 12 Maret 2016, ISSN :2502-6526 (Surakarta :2016)

Nana Syaodih Sukmadinat. (2011). Metode Penelitian Pendidikan, Bandung: RemajaRosdakarya.

Suharsimi Arikunto. (2001). Prosedur Penelitian Suatu Pendekatan Praktek, Jakarta: PT. Rineka Cipta. 